\title{
Phosphorus Fractions in Contrasting Soil Orders in Central India
}

\author{
Jayshive Patidar $^{1}$, Y.M. Sharma ${ }^{1}$ and G.S. Tagore ${ }^{1 *}$ \\ Deptt. of Soil Science and Agricultural Chemistry, Jawaharlal Nehru Krishi Vishwa \\ Vidyalaya, Jabalpur, India \\ *Corresponding author
}

\section{Keywords \\ Phosphorus, \\ Vertisol, Inceptisol, Alfisol, Ca-P, Fe-P, Al-P, Saloid P, Occluded P \\ Article Info \\ Accepted: \\ 26 December 2018 \\ Available Online: \\ 10 January 2019}

\section{A B S T R A C T}

In present study, phosphorus fractions in representative agricultural soils belonging to three soil orders Vertisol, Inceptisol and Alfisol JNKVV, Farm, Jabalpur were investigated. Result revealed that the highest soil $\mathrm{pH}$ analysed in Vertisols with the range 7.57 to 7.68 followed by Alfisols range 6.37 to 7.18 and low pH found in Inceptisols, which 6.27 to 6.72 soil orders, respectively. The EC was existed as normal in all the orders $<1 \mathrm{dS} \mathrm{m} \mathrm{m}^{-1}$ at $25^{\circ} \mathrm{C}$. The organic carbon content was recorded in different soil orders ranged from 4.60 to $6.60 \mathrm{~g} \mathrm{~kg}^{-1}$. The $\mathrm{CaCO}_{3}$ content was found to be ranged from 40 to 70 $\mathrm{g} \mathrm{kg}^{-1}$. Overall, the soils are non-calcareous in nature. Vertisols have the highest CEC value fallowed by Inceptisols and Alfisols, which have minimum $\mathrm{CEC}$ value. The available $\mathrm{N}$ content in soils varied from 239.14 to $302.70 \mathrm{~kg} \mathrm{ha}^{-1}$ in different soil orders. The available phosphorus content in three soils orders varied from 11.24 to $30.79 \mathrm{~kg} \mathrm{ha}^{-1}$. The available $\mathrm{K}$ ranged from 308.32 to $345.60 \mathrm{~kg} \mathrm{ha}^{-1}$ in Vertisols, 289.76 to 336.08 $\mathrm{kg} \mathrm{ha}^{-1}$ in Inceptisols and it was ranged from 276.96 to $322.80 \mathrm{~kg} \mathrm{ha}^{-1}$ in Alfisols. The available $\mathrm{N}, \mathrm{P}$ and $\mathrm{K}$ were low to medium in different soil orders. Vertisols and Inceptisols were found to be in order of $\mathrm{Ca}-\mathrm{P}>\mathrm{Al}-\mathrm{P}>$ Occluded-P $>\mathrm{Fe}-\mathrm{P}>$ Saloid-P. Whereas, Alfisols in order of $\mathrm{Ca}-\mathrm{P}>\mathrm{Fe}-\mathrm{P}>\mathrm{Al}-\mathrm{P}>\mathrm{Occluded}-\mathrm{P}>\mathrm{Saloid}-\mathrm{P}$. The $\mathrm{Ca}-\mathrm{P}$ was found high in the Vertisols. But Fe-P and Al-P were recorded maximum under Alfisols.

\section{Introduction}

Phosphorus (P) is essential element for plant growth as well as an important component in the developmental processes of agricultural crops (Withers et al., 2008). Approximately two-thirds of inorganic $\mathrm{P}$ and one third of organic $\mathrm{P}$ are not available in soil, especially in soils of variable charges. The rate of $\mathrm{P}$ use during crop growth is very low. Phosphates fixed by $\mathrm{Fe}, \mathrm{Al}$, and $\mathrm{Ca}$ in soils is a major cause of low phyto-availability (McBeath et al., 2005), because at least 70 to $90 \%$ of $P$ that enters the soil is fixed, making it difficult for plants to absorb and use (Lei et al., 2004).

Organic inputs have been reported to increase $\mathrm{P}$ availability in P-fixing soils and humic substances enhance the bioavailability of $\mathrm{P}$ fertilizers in acidic soils (Hua et al., 2008). Decomposition products from manure such as humic acids and citrate were reported to have greater affinity for $\mathrm{Al}$ oxides than for $\mathrm{PO}_{4}$. The term available-P is often used to describe 
the amount of soil $\mathrm{P}$ that can be extracted from solution or taken up by plant roots and utilized by the plant to growth and develop during its life cycle.

The concentration of available-P is always low because of continuous plant uptake. Phosphorus fertilizer efficiency in acid soils is less than $20 \%$ due to $\mathrm{P}$ fixation through $\mathrm{P}$ precipitation by soluble $\mathrm{Fe}$ and $\mathrm{Al}$, and adsorption by Fe oxides.

The $\mathrm{P}$ is a critical element in agricultural ecosystem given its complex transformation in soil thus making its availability to plant difficult especially in tropics. Its deficiency is one of the major nutritional constraints to crop production in Indian vertisols (Bansal and Sekhon, 1994). Muralidharudu et al., (2011) reported only 8 and $11 \%$ districts as high $P$ in India and Madhya Pradesh, respectively. Soil phosphorus exists in inorganic $\mathrm{P}$ and organic $\mathrm{P}$ forms.

These $\mathrm{P}$ forms differ in their behavior and fate in soils (Turner et al., 2007). The organic $\mathrm{P}$ can be released through mineralization processes mediated by soil organisms and plant roots in association with phosphates secretion. These processes are highly influenced by soil moisture, temperature, surface physical chemical properties, and soil $\mathrm{pH}$ and Eh. Organic $\mathrm{P}$ transformation has a great influence on the overall bioavailability of $\mathrm{P}$ in soil (Turner et al., 2007).

It is therefore important to consider both organic and inorganic $\mathrm{P}$ fractions for soil $\mathrm{P}$ fertility evaluation. It can serve as an indicator for proper nutrient management. Shen et al., 2004 concluded that fractions of $\mathrm{P}$ can provide an effective approach for investigating soil $\mathrm{P}$ availability and $\mathrm{P}$ inter conversion among soil $\mathrm{P}$ fractions from different $\mathrm{P}$ pools. Hence, the study was made to assess the fraction of $\mathrm{P}$ in different soil orders.

\section{Materials and Methods}

\section{Description of study area and sites}

Jawaharlal Nehru Krishi Vishwa Vidyalaya, Jabalpur, is situated $23^{\circ} 12^{\prime} 57^{\prime}$ "latitude and $79^{\circ} 56^{\prime} 49^{\prime \prime}$ longitude and altitude of $383.3 \mathrm{~m}$ above mean sea level. Breeder Seed Production of Field Crops (BSP-FC) in which dominant soils were Vertisol, classified as Typic Haplusterts, Family-Very fine montmorrilonite hyperthermic (Tripathi1998) and Inceptisol, Vertic Ustochrept, fine mixed hyperthermic (Kulkarni, 1986). The soils of BSP-FC Farm are clayey in texture (Fig. 1).

Krishi Nagar Research Farm in which soil order was Alfisol and classified as Typic and Vertic Haplustalf, Fine loamy and mixed, hyperthermic, locally knew as sehra soils. The texture was found to be sandy clay loam and sandy loam (Dhakad, 2017)

Breeder Seed Production of Groundnut (BSPGroundnut) in which soil type was Inceptisol and classified as Typic Ustochrept, Fine loamy and mixed, hyperthermic (Tripathi, 1998).

\section{Physico-chemical properties of soils}

The soil $\mathrm{pH}$ was measured in a soil: water ratio of 1: 2.5 using the $\mathrm{pH}$ meter and supernatant of same was used for electrical conductivity determination with the help of conductivity-meter (Jackson, 1973). Organic carbon in soil was determined using method as described by (Walkley and Black, 1934). The calcium carbonate in soil was carried out using rapid back titration method as described by (Jackson, 1973). The CEC of soil was analyzed by leaching it with $1 \mathrm{~N}$ neutral $\mathrm{NH}_{4} \mathrm{OAc}$ solution as described by (Jackson, 1973).The particle size analysis (clay percent) of soil was determined by Bouyoucous hydrometer method (Bouyoucous, 1962). 
Available nitrogen was determined as per method given by Subbiah and Asija (1956). Available phosphorus was determined by 0.5 M sodium bicarbonate by Olsen et al., (1954) and then read on Spectrophotometer. Available potassium (K) was extracted with 1 $\mathrm{N} \mathrm{NH}_{4} \mathrm{OAc}$ and then measured by Flame Photometer (Jackson, 1973).

\section{Determinations of phosphorus fractions}

The procedure of Chang and Jackson (1957) as modified by Peterson and Corey (1966) was followed for fractionation of soil phosphorus. The sequence of Saloid-P, Al-P, Fe-P, Occluded-P and Ca-P from the each sample was passed through a 60 mesh sieve. The soil extractant for various fractions in sequence were as follow:-
Saloid-P extracted by $1 \mathrm{~N} \mathrm{NH}_{4} \mathrm{CI}$

Al-P extracted by $0.5 \mathrm{~N} \mathrm{NH}_{4} \mathrm{~F}$ buffered at $\mathrm{pH}$ 8.2

Fe-P extracted by $0.1 \mathrm{M} \mathrm{NaOH}$

Occluded-P extracted by $0.1 \mathrm{M} \mathrm{NaOH}$

Ca-P extracted by $0.5 \mathrm{~N} \mathrm{H}_{2} \mathrm{SO}_{4}$

In each fraction take $5 \mathrm{ml}$ extract in $25 \mathrm{ml}$ of volumetric flask for determination after dilution shake the content and add $4 \mathrm{ml}$ reagent mixture (Ascorbic acid) the contents of flasks were shaken well and diluted to the mark. Colour intensity was measured in spectrophotometer within 10 minutes after setting the instrument to 100 reading of transmittance with blank prepared. The amount of phosphorus was calculated as $\mathrm{P}$ in $\mathrm{kg} \mathrm{ha}^{-1}$.

\section{Flow chart of phosphorus fractions}

$1 \mathrm{~g}$ of soil samples taken in a $50 \mathrm{ml}$ centrifuge tube

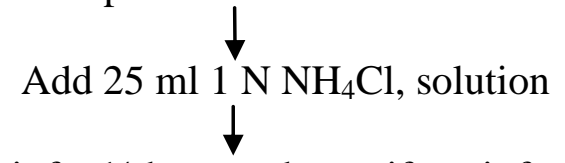

Shake it for $1 / 2$ hour and centrifuge it for $5 \mathrm{~min}$

$25 \mathrm{ml}$ of $0.5 \mathrm{~N} \mathrm{NH}_{4} \mathrm{~F}$ was added in the same tube after filtering

Shake it for $1 / 2$ hour and centrifuge it for $5 \mathrm{~min}$<smiles></smiles>

The residue of tube is washed by adding $25 \mathrm{ml}$ of $\mathrm{NaCl}$

$25 \mathrm{ml}$ of $0.1 \mathrm{M} \mathrm{NaOH}$, was added in the same tube after filtering

Shake it for 17 hours and then centrifuging of $5 \mathrm{~min}$

The residue of tube is washed by adding $25 \mathrm{ml}$ of $\mathrm{NaCl}$

$25 \mathrm{ml}$ of $0.1 \mathrm{M} \mathrm{NaOH}$, was added in the same tube after filtering 


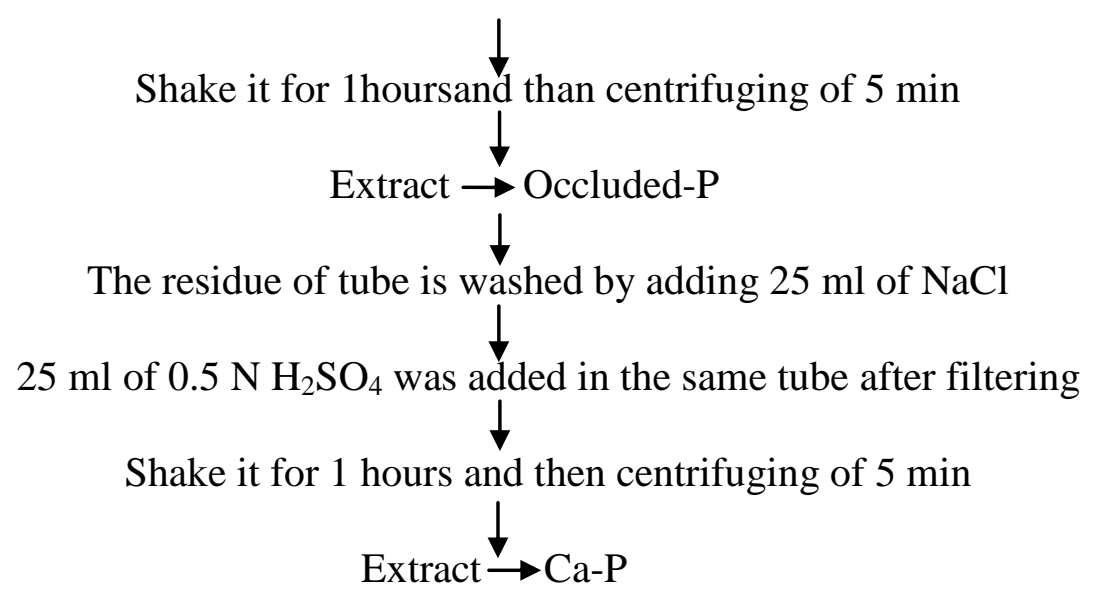

\section{Results and Discussion}

\section{Status of physico-chemical properties of soil}

The soil $\mathrm{pH}$ of different soil order of JNKVV farm Jabalpur, found to be 7.57, 7.59 and 7.68, 6.37, 6.95 and 7.18 and 6.72, 6.27 and 6.35 in $\mathrm{V}_{1}, \mathrm{~V}_{2}$ and $\mathrm{V}_{3}$ (Vertisols), $\mathrm{A}_{1}, \mathrm{~A}_{2}$ and $\mathrm{A}_{3}$ (Alfisols) and $\mathrm{I}_{1}, \mathrm{I}_{2}$ and $\mathrm{I}_{3}$ (Inceptisols) soil orders, respectively. The EC ranged from 0.07 to $0.35 \mathrm{dS} \mathrm{m}^{-1}$. It was safe in limit the three soil order $<1 \mathrm{dSm}^{-1}$ at $25^{\circ} \mathrm{C}$. The organic carbon content in soil ranged from 4.60 to $6.60 \mathrm{~g} \mathrm{~kg}^{-1}$ in different orders of soil. The highest content of OC is recorded in Vertisol, which were 6.60, 5.92 and $5.87 \mathrm{~g} \mathrm{~kg}^{-1}$ in $\mathrm{V}_{2}$, $\mathrm{V}_{1}$ and $\mathrm{V}_{3}$, respectively. In Alfisols, the $\mathrm{OC}$ content found to be $5.33,5.25$, and $4.80 \mathrm{~g} \mathrm{~kg}^{-1}$ in $A_{1}, A_{3}$ and $A_{2}$, respectively. However, organic carbon content in Inceptisols was observed to be low in $\mathrm{I}_{3}, \mathrm{I}_{2}$ and $\mathrm{I}_{1}$ which having value of $5.64,5.55$ and $4.60 \mathrm{~g} \mathrm{~kg}^{-1}$ respectively. The $\mathrm{CaCO}_{3}$ content was found to be $40,60,45 \mathrm{~g} \mathrm{~kg}^{-1}$ and $60,70,40 \mathrm{~g} \mathrm{~kg}^{-1}$ and $65,70,45 \mathrm{~g} \mathrm{~kg}^{-1}$ in $\mathrm{V} 1, \mathrm{~V} 2$ and $\mathrm{V}_{3}$ (Vertisols), $\mathrm{A}_{1}, \mathrm{~A}_{2}$ and $\mathrm{A}_{3}$ (Alfisols) and $\mathrm{I}_{1}, \mathrm{I}_{2}$ and $\mathrm{I}_{3}$ (Inceptisols) soil orders, respectively. Raghuwanshi et al., (1992) analyzed Brown soils were slightly acidic (pH 5.6 to 6.6) while the black soil of Jabalpur was neutral to alkaline $(\mathrm{pH}$ 7.2). Organic carbon was found to be low in Inceptisols and the high in
Vertisols (Fig. 2). The OC high might be due to incorporation of organic matter on the upper layer of the soil, through roots and other plant residues and manures. The crop species and cropping systems that may also play an important role in maintaining SOC stock because both quantity and quality of their residues that are returned to the soils vary greatly affecting their turnover or residence time in soil and thus its quality. Similar ranges in $\mathrm{pH}$ values were also reported by Tripathi et al., (1994). Similar results for various black soils were also reported by Tomar (1968) and Singh et al., (2014). It is concluded that the soils are non calcareous in nature. Similar results were reported by Singh et al., (2014). The highest CEC content was found to be $58.24,62.78,55.23 \mathrm{cmol}(\mathrm{p}+) \mathrm{kg}^{-1}$ in $\mathrm{V}_{1}, \mathrm{~V}_{2}$ and $\mathrm{V}_{3}$ (Vertisols) fallowed by $44.95,48.21$, $47.53 \mathrm{cmol}(\mathrm{p}+) \mathrm{kg}^{-1}$ and 45.75, 48.94, 46.72 cmol (p+) kg $\mathrm{kg}^{-1}$ in, $\mathrm{A}_{1}, \mathrm{~A}_{2}$ and $\mathrm{A}_{3}$ (Alfisols) and $\mathrm{I}_{1}, \mathrm{I}_{2}$ and $\mathrm{I}_{3}$ (Inceptisols) soil orders. The minimum CEC was existed in Alfisols and Inceptisols. However it was the highest in Vertisols, Existence of higher CEC in soils of Vertisols might be due to presence of higher clay content. Pathak (1983) reported that CEC of clay soils derived from basaltic rocks increased with clay content. Similar results were also reported by Matike et al., (2011) and Singh (2014) (Table 1-3). 
Table.1 Details of soil used

\begin{tabular}{|c|c|c|c|c|c|c|}
\hline Farm & $\begin{array}{c}\text { Soil } \\
\text { orders }\end{array}$ & Site & Latitude & Longitude & $\begin{array}{c}\text { Cropping } \\
\text { system }\end{array}$ & $\begin{array}{c}\text { Sample } \\
\text { No. }\end{array}$ \\
\hline \multirow{3}{*}{$\begin{array}{l}\text { BSP-Field } \\
\text { Crops }\end{array}$} & \multirow[t]{3}{*}{ Vertisols } & $\left(\mathrm{V}_{1}\right)$ & N-2313'02.4"' & E-7956'40.7' & Soybean-Wheat & \multirow[t]{3}{*}{3} \\
\hline & & $\left(V_{2}\right)$ & $\mathrm{N}-23^{\circ} 12^{\prime} 50.1^{\prime \prime}$ & E-79॰56’47.0” & Soybean-Wheat & \\
\hline & & $\left(V_{3}\right)$ & $\mathrm{N}-23^{\circ} 13^{\prime} 44.6^{\prime \prime}$ & E-79॰56’36.7" & Soybean-Wheat & \\
\hline \multirow{3}{*}{$\begin{array}{l}\text { Krishi } \\
\text { Nagar } \\
\text { Research } \\
\text { Farm }\end{array}$} & \multirow[t]{3}{*}{ Alfisols } & $\left(A_{1}\right)$ & N-2312'17.6" & E-79॰57’17.6" & Rice-Wheat & \multirow[t]{3}{*}{3} \\
\hline & & $\left(\mathrm{A}_{2}\right)$ & $\mathrm{N}-23^{\circ} 12^{\prime} 18.2^{\prime \prime}$ & E-79॰57’32.1" & Rice-Wheat & \\
\hline & & $\left(\mathrm{A}_{3}\right)$ & $\mathrm{N}-23^{\circ} 12^{\prime} 27.8^{\prime \prime}$ & E-7957'24.3” & Rice-Wheat & \\
\hline \multirow{3}{*}{$\begin{array}{l}\text { BSP- } \\
\text { Groundnut }\end{array}$} & \multirow[t]{3}{*}{ Inceptisols } & $\left(\mathrm{I}_{1}\right)$ & $\mathrm{N}-23^{\circ} 12^{\prime} 53.1^{\prime \prime}$ & E-7957'59.2” & Rice-Wheat & \multirow[t]{3}{*}{3} \\
\hline & & $\left(\mathrm{I}_{2}\right)$ & N-2312'56.7' & E-7957’47.5” & Rice-Wheat & \\
\hline & & $\left(\mathrm{I}_{3}\right)$ & $\mathrm{N}-23^{\circ} 13^{\prime} 04.8^{\prime \prime}$ & E-7957'48.1" & Rice-Wheat & \\
\hline
\end{tabular}

Table.2 Soil properties of different soils

\begin{tabular}{|c|c|c|c|c|c|c|c|c|c|}
\hline \multirow[t]{2}{*}{ Site } & \multirow[t]{2}{*}{ pH } & \multirow[t]{2}{*}{ 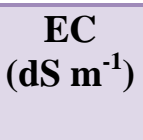 } & \multirow[t]{2}{*}{$\begin{array}{c}\mathrm{OC} \\
\left(\mathrm{g} \mathrm{kg}^{-1}\right)\end{array}$} & \multirow[t]{2}{*}{$\begin{array}{l}\mathrm{CaCO}_{3} \\
\left(\mathrm{~g} \mathrm{~kg}^{-1}\right)\end{array}$} & \multirow{2}{*}{$\begin{array}{c}\text { CEC } \\
{\left[\operatorname{cmol}^{-1}+\right)} \\
\left.\mathrm{kg}^{-1}\right]\end{array}$} & \multirow[t]{2}{*}{$\begin{array}{l}\text { Clay } \\
(\%)\end{array}$} & \multicolumn{3}{|c|}{$\begin{array}{l}\text { Available major } \\
\text { nutrient }\left(\mathrm{kg} \mathrm{ha}^{-1}\right)\end{array}$} \\
\hline & & & & & & & $\mathbf{N}$ & $\mathbf{P}$ & K \\
\hline (V1) & 7.57 & 0.35 & 5.92 & 40.00 & 58.24 & 50 & 267.79 & 16.24 & 328.68 \\
\hline (V2) & 7.59 & 0.26 & 6.60 & 60.00 & 62.78 & 55 & 302.70 & 11.09 & 308.32 \\
\hline (V3) & 7.68 & 0.22 & 5.87 & 45.00 & 55.23 & 52 & 250.88 & 15.15 & 345.60 \\
\hline (A1) & 6.37 & 0.16 & 5.33 & 60.00 & 44.95 & 25 & 279.97 & 30.53 & 298.08 \\
\hline (A2) & 6.95 & 0.12 & 4.80 & 70.00 & 48.21 & 20 & 245.06 & 30.79 & 276.96 \\
\hline (A3) & 7.18 & 0.15 & 5.25 & 40.00 & 47.53 & 22 & 276.97 & 24.91 & 322.80 \\
\hline (I1) & 6.72 & 0.08 & 4.60 & 65.00 & 45.75 & 25 & 239.14 & 21.34 & 336.08 \\
\hline (I2) & 6.27 & 0.09 & 5.55 & 70.00 & 48.94 & 30 & 251.06 & 17.60 & 323.36 \\
\hline (I3) & 6.35 & 0.07 & 5.64 & 45.00 & 46.72 & 32 & 272.23 & 22.00 & 289.76 \\
\hline
\end{tabular}

Table.3 Phosphorus fraction $\left(\mathrm{kg} \mathrm{ha}^{-1}\right)$ in different soils

\begin{tabular}{|l|c|c|c|c|c|c|c|}
\hline Sites & Saloid-P & Al-P & Fe-P & Occl-P & Ca-P & Res-P & Total-P \\
\hline$\left(\mathbf{V}_{\mathbf{1}}\right)$ & 10.36 & 18.75 & 11.12 & 12 & 47.74 & 32.84 & 132.82 \\
\hline$\left(\mathbf{V}_{\mathbf{2}}\right)$ & 8.72 & 19.51 & 16.08 & 16.37 & 38.35 & 32.02 & 122.32 \\
\hline$\left(\mathbf{V}_{\mathbf{3}}\right)$ & 12.46 & 24.48 & 13.71 & 17.62 & 31.99 & 38.35 & 129.62 \\
\hline$\left(\mathbf{A}_{\mathbf{1}}\right)$ & 11.56 & 18.69 & 26.53 & 13.37 & 34.15 & 17.08 & 140.38 \\
\hline$\left(\mathbf{A}_{\mathbf{2}}\right)$ & 9.74 & 25.27 & 28.02 & 18.65 & 32.89 & 18.79 & 145.37 \\
\hline$\left(\mathbf{A}_{\mathbf{3}}\right)$ & 8.51 & 22.7 & 30.93 & 20.21 & 43.41 & 8.7 & 136.46 \\
\hline$\left(\mathbf{I}_{\mathbf{1}}\right)$ & 7.11 & 19.73 & 12.03 & 16.75 & 28.33 & 26.62 & 134.57 \\
\hline$\left(\mathbf{I}_{\mathbf{2}}\right)$ & 9.17 & 17.69 & 11.27 & 16.85 & 33.59 & 7.95 & 132.51 \\
\hline$\left(\mathbf{I}_{\mathbf{3}}\right)$ & 10.55 & 19.54 & 12.04 & 15.82 & 30.12 & 22.11 & 134.17 \\
\hline
\end{tabular}


Fig.1 Location of soil sampling

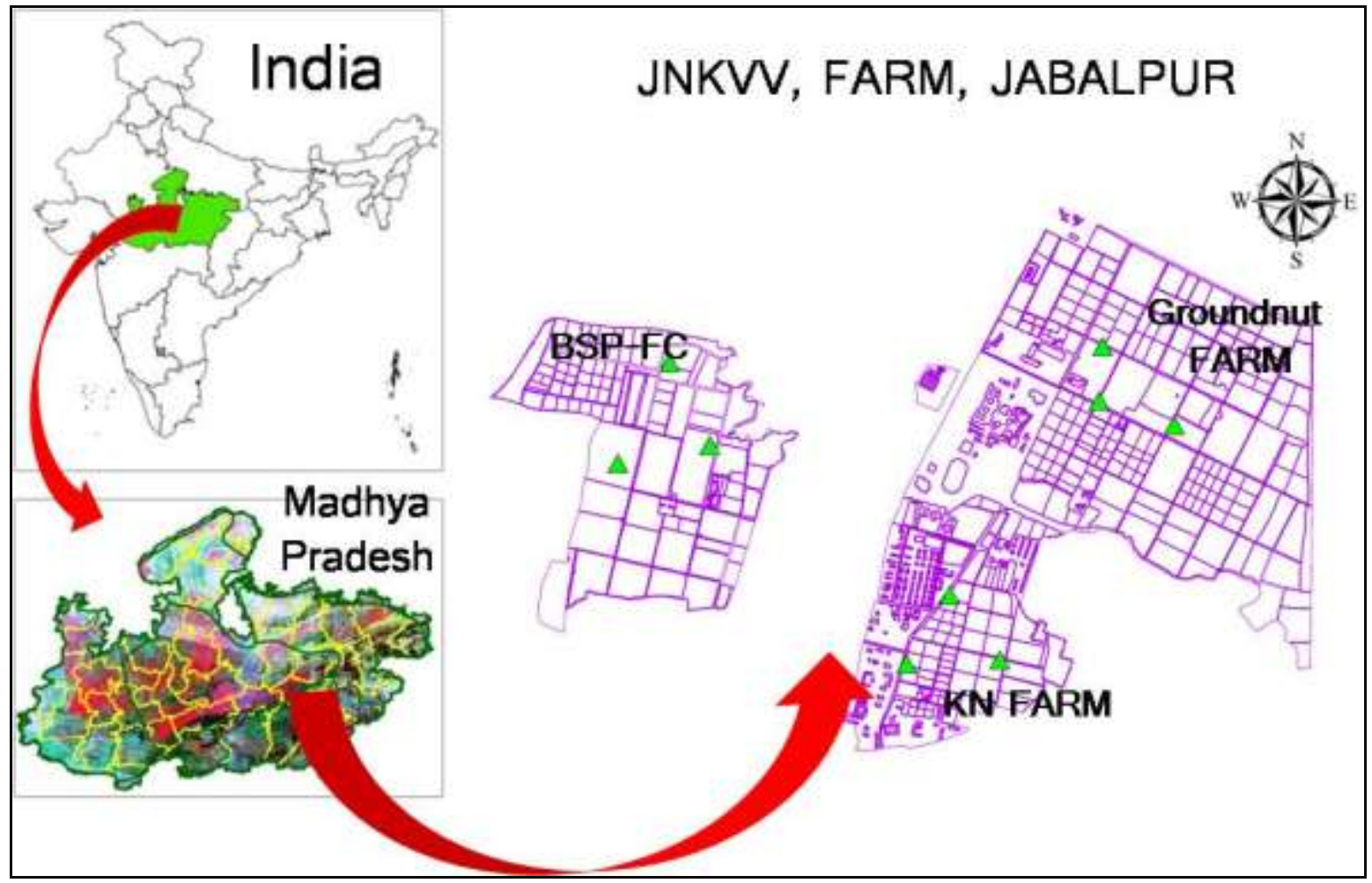

Fig.2 Percent contribution of different fraction of $\mathrm{P}$ soils

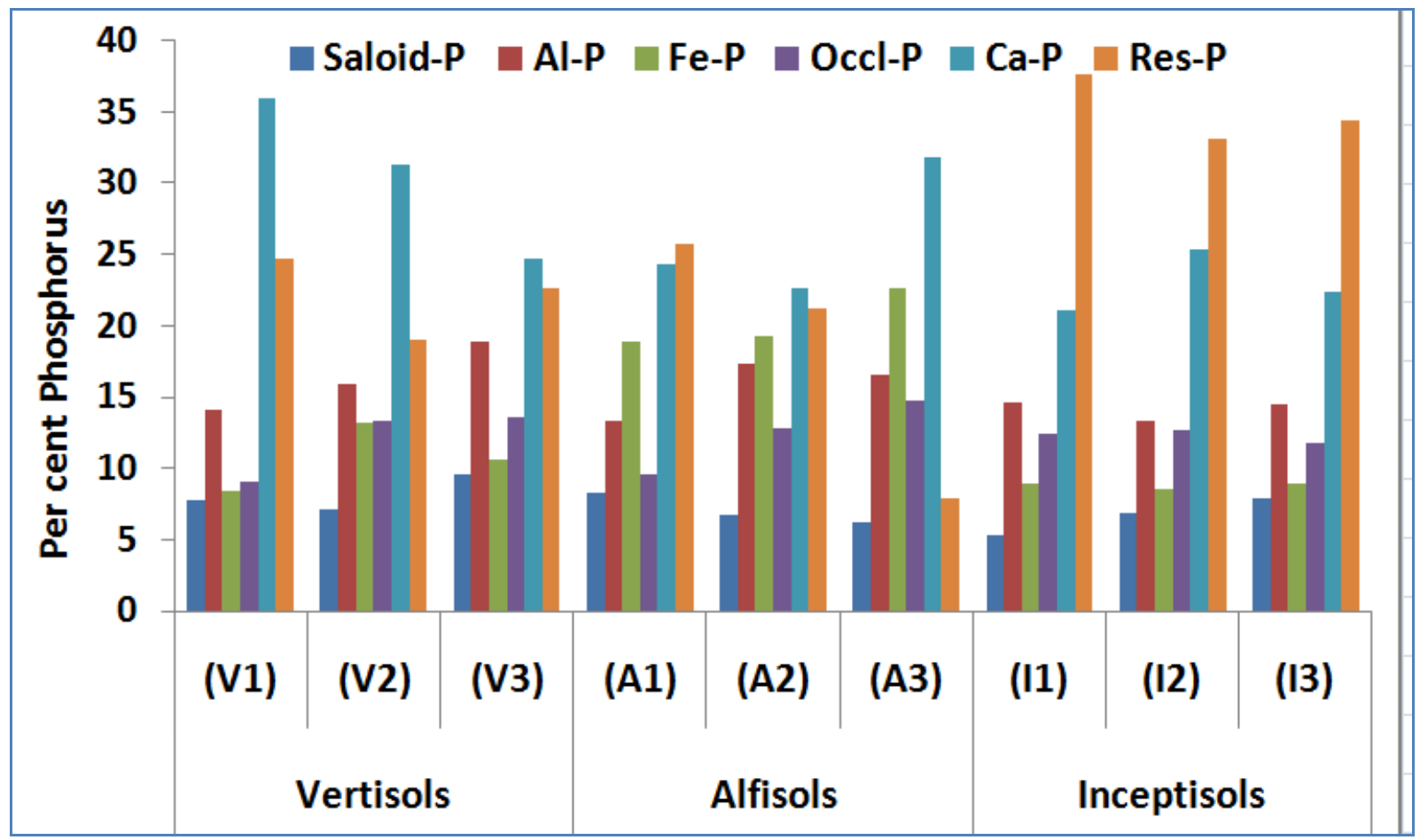




\section{Available major nutrients status in soils}

\section{Available N}

In Inceptisols, $\mathrm{I}_{3}, \mathrm{I}_{2}$ and $\mathrm{I}_{1}$ which had value of $272.23, \quad 251.06$ and $239.14 \mathrm{~kg} \mathrm{ha}{ }^{-1}$, respectively. In Alfisols, it was recorded to be 279.97, 276.83 and $245.06 \mathrm{~kg} \mathrm{ha}^{-1}$ in $\mathrm{A}_{1}, \mathrm{~A}_{3}$ and $\mathrm{A}_{2}$, respectively. However, Vertisols, which having value of $302.70,267.79$ and $250.88 \mathrm{~kg} \mathrm{ha}^{-1}$ in $\mathrm{V} 2, \mathrm{~V} 1$ and $\mathrm{V} 3$, respectively. The low to medium nitrogen content in the soils is attributed due to high temperature, removal of organic matter leading to nitrogen deficiency. The medium nitrogen status may be due to application of $\mathrm{N}$ fertilizer recommended for the crops. Soils with higher levels might be the contribution from the legumes crops and very little tillage. Similar results were reported by Dubliya, (2011) and Singh et al., (2014); Ravikumar and Somashekar (2014).

\section{Available P}

The available phosphorus content in Vertisols, Alfisols and Inceptisols i.e., V1, V2 and V3; A1, A2 and A3; I1, I2 and I3 was recorded to be $16.24,11.09$ and $15.15 \mathrm{~kg} \mathrm{ha}^{-1}$; 30.5330 .79 and $24.91 \mathrm{~kg} \mathrm{ha}^{-1} ; 22.00,17.60$ and $22.00 \mathrm{~kg} \mathrm{ha}^{-1}$ respectively. The high accumulation of $\mathrm{P}$ in soils is attributed to the regular application of phosphatic fertilizers and the immobile nature of phosphate ions in soils. Results were supported by Ravikumar and Somashekar (2014) similar results were reported by Dubliya, 2011 and Singh et al., (2014).

\section{Available K}

The available $\mathrm{K}$ content in $\mathrm{V}_{1}, \mathrm{~V}_{2}$ and $\mathrm{V}_{3}$ (Vertisols) and $\mathrm{A}_{2}, \mathrm{~A}_{3}$ and $\mathrm{A}_{1}$ (Alfisols) were $328.68, \quad 308.32$ and $345.60 \mathrm{~kg} \mathrm{ha}^{-1}$ and $276.96, \quad 352.80$ and $358.08 \mathrm{~kg} \mathrm{ha}{ }^{-1}$ respectively. The $\mathrm{K}$ was recorded in $\mathrm{I}_{3}, \mathrm{I}_{1}$ and
$\mathrm{I}_{2}$ (Inceptisols) with value of $389.76,346.08$ and $323.36 \mathrm{~kg} \mathrm{ha}^{-1}$ respectively. The high status of $\mathrm{K}$ in these soils may be due to predominance of $\mathrm{K}$ rich minerals in parent material. Similar results reported by Ravikumar and Somashekar (2014).

Phosphorus fractions in different soil orders

\section{Vertisols}

In Vertisols i.e., $\mathrm{V}_{1}$ and $\mathrm{V}_{2}$, the $\mathrm{P}$ fractions were analysed in soil order was in the abundance: $\quad \mathrm{Ca}-\mathrm{P}>\mathrm{Al}-\mathrm{P}>\mathrm{O}$ Occluded-P $>\mathrm{Fe}-$ $\mathrm{P}>$ Saloid-P which value was $47.74>18.75>$ $12.00>11.12>10.36$ and $38.35>19.51>$ $16.37>16.08>8.72 \mathrm{~kg} \mathrm{ha}{ }^{-1}$ and percent contribution was 35.94> 14.12>9.03> $8.38>7.80 \quad 31.35>15.95>13.38>13.15>7.13$ of total-P, respectively. However, in $\mathrm{V}_{3}$ soil order followed $\mathrm{Ca}-\mathrm{P}>\mathrm{Al}-\mathrm{P}>$ Occluded $-\mathrm{P}>\mathrm{Fe}-$ P>Saloid-P, Which value was $31.99>24.48>17.62>13.71>12.46 \mathrm{~kg} \mathrm{ha}^{-1}$ and percent contribution was 24.68>18.89> $13.59>10.58>9.61$ of total-P, respectively. Ojo et al., (2015) stated that changes in the values of the $\mathrm{P}$ fractions in soils are significantly affected by soil type. Soil orders differ in their total P content because of interactions among soil parent material, weathering, and other pedogenic processes. In general, total $\mathrm{P}$ content is low in strongly weathered soil soils orders and high in young soil orders (Yang and Post, 2011). The content of the Ca-P ranks highest which was an indication of the fact that $\mathrm{Ca}-\mathrm{P}$ form contributed to the major source of $\mathrm{P}$ in black soil as reported by Kaushal (1995), Subehia et al., (2005), Samadi (2006) and Garg and Milkha (2010).

\section{Alfisols}

The result after analysis that the $\mathrm{P}$ fractions was in $A_{1}$ and $A_{2}$ of Alfisols soil order was in the abundance: $\mathrm{Ca}-\mathrm{P}>\mathrm{Fe}-\mathrm{P}>\mathrm{Al}-\mathrm{P}>$ Occluded- 
P $>$ Saloid-P, which value was $34.15>26.53>$ $18.69>13.37>11.56$ and $32.89>28.02>25.27>$ $18.65>9.74 \mathrm{~kg} \mathrm{ha}^{-1}$ percent contribution was $24.33>18.90>13.31>9.52>8.23$ and 22.63> $19.27>17.38>12.83>6.70$ of total-P, respectively. In $\mathrm{A}_{3}$ of Alfisols were shown in this order of abundance: $\mathrm{Ca}-\mathrm{P}>\mathrm{Fe}-\mathrm{P}>\mathrm{Al}-$ $\mathrm{P}>$ Occluded-P $>$ Saloid-P, Which value was $43.41>30.93>22.70>20.21>8.51 \mathrm{~kg} \mathrm{ha}^{-1}$ and percent contribution was $31.81>22.67>$ $16.63>14.81>6.24$ of total-P, respectively. Among the different $\mathrm{P}$ fractions, Ca-bound $\mathrm{P}$ was the dominant fraction in the Vertisols and Alfisols. The next-dominant fraction was nonoccluded $\mathrm{Al}$ and Fe-bound $\mathrm{P}$, which was highest in the Alfisols and Vertisols. $P$ occluded with in Fe-oxides and hydrous oxides fractions was highest in the Vertisol (Datta and Chandra, 2008). In Alfisols the amount and type of clay mineral especially 1:1 type clay minerals may contribute to more $\mathrm{P}$ sorption especially in tropical soil, particularly with low $\mathrm{pH}$ and high activity of $\mathrm{Al}$ and Fe (Dolui and Dasgupta, 1998).

\section{Inceptisols}

In Inceptisols, $I_{1}, I_{2}$ and $I_{3}$ soil orders the phosphorus fraction were followed this order of abundance: $\mathrm{Ca}-\mathrm{P}>\mathrm{Al}-\mathrm{P}>$ Occluded-P $>\mathrm{Fe}-$ $\mathrm{P}>$ Saloid-P, which value was $28.33>$ $19.73>16.75>16.75>7.11 ; 33.59>17.69>16.85$ $>11.27>9.17$ and $30.12>19.54>15.82>12.04>$ $10.55 \mathrm{~kg} \mathrm{ha}^{-1}$ and percent contribution was $21.05>14.66>12.45>8.94>5.28 ; 25.35>13.35>$ $12.72>8.51>6.92$ and $22.45>14.56>11.79>$ $8.97>7.86$ of total $\mathrm{P}$, respectively. The low content of Fe-P compared to Al-P and Ca-P might be due to the high activity of $\mathrm{Al}^{3+}$ and $\mathrm{Ca}^{2+}$ ions than $\mathrm{Fe}^{3+}$ ions in this soils. The results are in agreement with the findings of Patgundi et al., (1996). High P was reported in inceptisols which had little or no weathering or with very low decomposition (Yang and Post, 2011). Organic amendments are known to increase $\mathrm{P}$ availability in $\mathrm{P}$ fixing soils by governing the $\mathrm{P}$ fractions in soils (Reddy et al., 1999).

\section{References}

Bansal SK and Sekhon GS. 1994. Soil phosphorus in some Vertisols and crop response to phosphorus in these soils. Fertilizer News 39:13-17.

Bouyoucous GT. 1962. Improved hydrometer method for making particle size analysis of soils. Agronomy Journal 54:464-465. College of Tropical Agriculture and Human Resources, University of Hawaii.

Chang SC and Jackson ML.1957. Fraction of soil phosphorus. Soil Sci. 84: 133-134.

Datta N and Chandra S. 2008. Modeling timedependent phosphate buffering capacity in different soils as affected by bicarbonate and silicate ions. Australian Journal of Soil Research 46(4): 310

Dhakad R. 2017. Assessment of Fertility Status of Jawaharlal Nehru Krishi Vishwa Vidyalaya Farms for Developing Nutrient Management Strategies. M.Sc. Thesis JNKVV, Jabalpur (M.P.).

Dolui AK and Dasgupta M. 1998. Phosphate sorption- desorption characteristics of ferruginous soils (Alfisols) of eastern India. Agropedology, 8:76-83

Dubliya J. 2011. Soil health assessment of dusty acre farm under JNKVV, Jabalpur, Madhya Pradesh. M.Sc. Thesis, JNKVV, Jabalpur (M.P.).

Garg AK and Milkha SA. 2010. Effect of long term fertilizer management and crop rotation on accumulation and downward movement of phosphorous in semi-arid subtropical irrigated soil. Communication in Soil Sci. and plant Ana. Vol. 41: 848-864.

Hua, Q., Li, J., Zhou, J. 2008. Enhancement of phosphorus solubility by humic substances in Ferrosols. Pedosphere. 
18(4), 533-538.

Jackson ML.1973. Soil Chemical Analysis. Prentice Hall of India, Private Limited New Delhi 498p.

Kaushal A.1995. Forms of phosphorus in typic Haplusterts and their availability to wheat under long term fertilizer application and intensive cropping. Ph.D. Thesis. JNKW. Jabalpur. Pp. 158160.

Kulkarni R, Gupta GP and Bangar KS. 1986. A note on predicting management of kheri and adhartal series of soils. Journal of Indian Society Soil of Science 34: 641-643.

Lei, H., Zhu, C., Liu, X. 2004. Phosphorus adsorptiondesorption characteristics in acid soils under amendment. Acta Pedologica Sinica. 41, 636-640.

Matike DME, Ekosse GIE and Ngole VM. 2011. Physico-chemical properties of clayey soils used traditionally for cosmetics in Eastern Cape, South Africa. International Journal of the Physical Sciences 6(33): 7557-7566.

McBeath, T.M., Armstrong, R.D., Lombi, E., Mclaughlin, M.J. Holloway, R.E. 2005. Responsiveness of wheat (Triticum aestivum) to liquid and granular phosphorus fertilizers in southern Australian soils. Aust. J. Soil Res. 43, 203-212.

Muralidharudu Y, Sammi Reddy K, Mandal BN, Subba Rao A, Singh K and Sonekar S. 2011. GIS based soil fertility maps of different states of India. All India Coordinated Project on Soil Test Crop Response Correlation, Indian Institute of Soil Science, Bhopal pp: 1224.

Ojo AO, Adetunji MT and Okeleye KA. 2015. Soil fertility, phosphorus fractions, and maize yield as affected by poultry manure and single superphosphate. Int Scholarly Res Notices. Article ID 6162
Olsen SR, Cole CV, Vatanabe FS and Dean LA. 1954. Estimation of available phosphorus in soil by extraction with sodium bicarbonate. Circular United States, Department of Agriculture 93(9): 1-19.

Patagundi MS, Channal HT and Satyanarayana T. 1996. Distribution pattern and availability of phosphorus in some Vertisols of Tungabhadra command, Karnataka. Karnataka J Agric. Sci. 9(1): 33-39.

Pathak NKS. 1983. A study of the nutrient status of Adhartal series of Vertisols. M.Sc. Thesis, JNKVV, Jabalpur (M.P.).

Peterson GW and Corey RB. 1966. A modified Chang and Jackson procedure for routine fractionation of inorganic soil phosphate. Soil Sci. 30: 563-565.

Raghuwanshi DP, Tembhare BR and Gupta GP. 1992. Taxonomy of black and associated soils of Jabalpur, Pawarkheda and Indore Research Farms of M.P. JNKVV Research Journal 26: 12-14.

Ravikumar P and Somashekar RK. 2014. Spatial distribution of macronutrients in soils of Markandeya river basin, Belgaum, Karnataka, India. Proceedings of the International Academy of Ecology and Environmental Science 4(2): 81-94.

Reddy D, Subba Rao A and Takkar PN. 1999. Effects of repeated manure and fertilizer phosphorus additions on soil phosphorus dynamics under soybeanwheat rotation. Biology and Fertility of Soils 28:150-155.

Samadi A. 2006. Contribution of inorganic phosphorus fraction to plant nutrition in alkaline-calcareous soil. J. Agric. Sci. Techno. 8: 77-79.

Shen J, Li R, Zhang F, Fan J, Tang C and Rengel Z. 2004. Crop yields, soil fertility and phorphorus fractions in response to long term fertilization under 
the rice monoculture system on a calcareous soil. Field Crops Research 86: 225-238.

Singh R, Puri G, Dilliwar P and Amule FC. 2014. Soil health assessment of Adhartal series under Jawaharlal Nehru Krishi Vishwa Vidyalaya. National conference on soil health: A key to unlock and sustain production potential September 3-4 2014 held at Department of Soil Science and Agricultural Chemistry, College of Agriculture, JNKVV, Jabalpur (M.P.).

Subbiah BV and Asija GL. 1956. A rapid procedure for the determination of available nitrogen in soils. Current Science 25(8): 259-260.

Subehia S, Verma KS and Sharma SP. 2005. Effect of long term use of chemical fertilizer with and without organics on forms of soil acidity, phosphorus adsorption and crop yields in an acid soil. J. Indian Soc. Soil Sci. 53(3): 308314.

Tomar VS. 1968. Studies on magnesium in Madhya Pardesh. M.Sc. Thesis, JNKVV, Jabalpur (M.P.).

Tripathi PN. 1998. Detailed soil survey of different sections of JNKVV Farm at Jabalpur, Madhya Pradesh. M.Sc.
Thesis, JNKVV, Jabalpur (M.P.).

Tripathi SK. 1994. Evaluation of soil fertility status and quality of irrigation water of JNKVV Farms at Jabalpur, Madhya Pradesh. M.Sc. Thesis, JNKVV, Jabalpur (M.P.).

Turner BL, Richardson AE, Mullaney EJ. 2007. Inositol phosphates in soil: amounts, forms and significance of the phosphorylated inositol stereoisomers. Inositol Phosphates; Linking Agriculture and the Environment. CABI, Wallingford, UK 186-206

Walkley A and Black CA. 1934. An examination of Degt-Jreff method for determination soil organic matter and proposal for modification of the chromic acid titration method. Soil Science 37: 29-38.

Withers, P.J.A., Jarvie, H.P. 2008. Delivery and cycling of phosphorus in rivers, $\mathrm{A}$ review. Sci. Total Environ. 400, 379395.

Yang $\mathrm{X}$ and Post WM. 2011. Phosphorus transformations as a function of pedogenesis: A synthesis of soil phosphorus data using Hedley fractionation method. Biogeosciences 8(10): 2907-2916.

\section{How to cite this article:}

Jayshive Patidar, Y.M. Sharma and Tagore, G.S. 2019. Phosphorus Fractions in Contrasting Soil Orders in Central India. Int.J.Curr.Microbiol.App.Sci. 8(01): 3050-3059. doi: https://doi.org/10.20546/ijcmas.2019.801.325 